\title{
THE EFFECT OF DIFFERENT LEVELS OF DIETARY PROTEIN AND PROBIOTIC ON QUAIL PERFORMANCE
}

\author{
Aya G. Aabid*; M.A. AbdEl-Ghaffar; K.A. Said and A.M. Ali \\ Dept. Ani. and Poult. Prod., Fac. Environ. Agric. Sci., Suez Canal Univ., Egypt.
}

\begin{abstract}
This experiment was performed to study the effect of dietary protein level supplemented with yeast (Saccharomyces cerevisiae) or bacteria (lactic acid) as probiotic on performance of quail birds from 7 to 49 day. Four hundred and fifty unsexed quail chicks were assigned into ten treatment groups (45 birdes/ treatment) each having three replicates ( 15 birdes/ replicat). Chicks of group 1 (control group) were fed the starter and finisher diets ( 24 and $20 \% \mathrm{CP}$ ) that did not supplemented with probiotic. The chicks of groups 2, 3, 4 and 5 were fed the control starter and finisher diets (24 and 20\% CP) supplemented with 0.5 and $1 \mathrm{~g}$ of either yeast or bacteria per $\mathrm{kg}$ feed, respectively. Chicks of group 6 were fed the starter and finisher diets (22 and $18 \% \mathrm{CP}$ ) without probiotic. The chicks of groups 7,8,9 and 10 were fed the control starter and finisher diets (22 and 18\% CP) supplemented with 0.5 and $1 \mathrm{~g}$ of either yeast or bacteria per $\mathrm{kg}$ feed, respectively. Body weight, weight gain and feed intake were recorded. Feed conversion ratio (g, feed/g, gain) and protein conversion ratio (g, protein/g, gain) were calculated. At the end of the experiment carcass characteristics were measured, blood samples were taken to determine some blood protein constituents. The economic efficiency values of dietary treatments were calculated. The results revealed that, birds fed diet containing 24 and $22 \%$ crude protein diet supplemented with $1 \mathrm{~g}$ yeast/ $\mathrm{kg}$ diets during starter and grower period, respectively recorded significantly $(\mathrm{P} \leq 0.05)$ the best body weight, body gain, feed conversion ratio, protein utilization ratio and nutrients digestive compared with control diet. The inclusion of $1 \mathrm{~g}$ yeast/ $\mathrm{kg}$ diets in quail diets containing 24 or $22 \%$ crude protein recorded the higher economical efficiency (expressed as \% net revenue/feed cost) compared with control diet.
\end{abstract}

Key words: Saccharomyces cerevisiae, lactic acid, quail, growth performance, carcass, characteristics, blood parameters and digestion coefficient.

\section{INTRODUCTION}

Feed cost accounts constitute more than $70 \%$ of the total production cost. However, protein cost account about $15 \%$ of feed cost (Singh, 1990 and Banerjee, 1992). Thereby, protein content of the diet strongly affects costs. Protein of high quality with adequate amino acid balance is one of the most important nutrients for quail. In general, the crude protein content in diets of growing quail ranged from 24 to $27 \%$ (NRC, 1994; Shrivastav et al. 1999). However, Bariha et al. (2010) reported that the best $\mathrm{CP}$ levels under hot climate were $24 \%$ CP with $2800 \mathrm{Kcal} \mathrm{ME} / \mathrm{kg}$ during starter period and $22 \% \mathrm{CP}$ with $2900 \mathrm{Kcal}$ $\mathrm{ME} / \mathrm{kg}$ during finisher period phase under hot humid climate.

Currently, research highlights the role of probiotic microorganisms as a sound alternative to antibiotic growth promoters in poultry nutrition (Patterson and Burkholder, 2014). Many definitions of probiotics have been introduced, starting from Fuller (1989) who defined probiotics as a live microbial feed supplement which

\footnotetext{
* Corresponding author: Tel.: +201220714349

E-mail address: ayagamal328@yahoo.com
} 
beneficially affects the host by improving its intestinal microbial balance. However, according to the currently adopted definition by Food and Agriculture Organization and World Health Organization (2001), probiotics are: live microorganisms which when administered in adequate amounts confer a health benefit on the host.

The advantages of these probiotic as a growth prompter are that it neither has any residues in animal production nor exerts any antibiotic resistance by consumption (Gibson and Roberfroid, 2008). Many research conducted to evaluate the probiotics in poultry nutrition. It was reported that probiotics have a good impact on the poultry performance (Mountzouris et al. 2007), improve microbial balance, synthesize vitamins (Fuller, 1989), decrease $\mathrm{pH}$ and release bacteriocins (Rolfe, 2000), improve feed consumption in layers and broilers (Nahashon (et al. 1994).

The objective of the present study to examine the effect of different levels of crude protein (CP) and probiotics on performance, nutrients digestibility, carcass characteristics, some blood parameters and economic profit of quail under North Sinai conditions.

\section{MATERIALS AND METHODS}

The present study was carried out at the experimental farm, Faculty of Environmental Agriculture Sciences, Suez Canal University, Al-Arish, North Sinai, Egypt. The trial lasted 6 weeks from March to May 2015.

\section{Experimental Birds and Management}

A total number of 450 unsexed quail chicks of seven day age, weighed about $26.65 \mathrm{~g}$ were used. Quail birds were randomly allotted to 10 treatments (45 birds per treatment) in 3 replicates (15 birds/ replicate). Birds were housed in battery cages, kept under similar environmental and managerial conditions during 7-49 days of age. Feed and water were offered adlibitum all over the experimental period.

\section{Experimental Design and Feeding Program}

Experimental diets were corn-soybean based and contain 24 and $20 \%$ crude protein (standard protein requirement according to NRC 1994, recommendation) in starting period or 22 and $18 \%$ crude protein in growing period and nearly similar in other nutrients and metabolizable energy. Each protein level either supplemented with different three levels of yeast or bacteria content $(0.0,0.5$ and 1.00 $\mathrm{g} / \mathrm{kg}$ diets) to formulate ten different experimental diets.

The ingredient composition and chemical analysis of the experimental diets used in the starting and growing periods are presented in Tables 1 and 2. Quail chicks of group 1 (control group) were fed on the experimental diet containing 24 and $20 \%$ CP without any probiotic supplementation during starter and grower periods respectively. Groups 2, 3, 4 and 5 were fed on diets containing (24 and 20\% CP) supplemented with either yeast or bacteria at 0.5 and 1 $\mathrm{g} / \mathrm{kg}$ level during starter and grower periods respectively.

Group 6 was fed on the experimental diet containing 22 and 18\% CP without any probiotic supplementation during starter and grower period respectively. Groups 7, 8,9 and 10 were fed diets containing (22 and $18 \% \mathrm{CP}$ ) supplemented with either yeast or bacteria at 0.5 and $1 \mathrm{~g} / \mathrm{kg}$ level during starter and grower periods respectively.

\section{Data Collection}

Birds were weighed at $49^{\text {th }}$ day and the average live body weight gain (LBWG) and feed intake (FI) were calculated. Feed conversion ratio (FCR) was calculated as $g$ $\mathrm{fed} / \mathrm{g}$ gain however, protein utilization ratio (PUR) was g protein/g gain. To determine nutrients digestibility, chemical analyses of experimental diets and dried excreta were determined according to AOAC (2000), also fecal nitrogen was determined according 
SINAI Journal of Applied Sciences (ISSN: 2314-6079) Vol. (5) Is. (1), Apr. 2016

Table (1): Composition and calculated analyses of experimental diets in starter period (7-28 day).

\begin{tabular}{|c|c|c|c|c|c|c|c|c|c|c|}
\hline Ingredient & $\begin{array}{c}\mathrm{T}_{1} \\
\text { (Control) } \\
\end{array}$ & $\mathbf{T}_{2}$ & $\mathbf{T}_{3}$ & $\mathbf{T}_{4}$ & $\mathbf{T}_{5}$ & $\mathbf{T}_{6}$ & $\mathbf{T}_{7}$ & $\mathbf{T}_{8}$ & $\mathbf{T}_{9}$ & $\mathbf{T}_{10}$ \\
\hline Yellow corn & 60 & 60 & 60 & 60 & 60 & 65.54 & 65.54 & 65.54 & 65.54 & 65.54 \\
\hline Soybean & 36.57 & 36.57 & 36.57 & 36.57 & 36.57 & 30.63 & 30.63 & 30.63 & 30.63 & 30.63 \\
\hline Di-calcium phosphate & 0.83 & 0.83 & 0.83 & 0.83 & 0.83 & 0.93 & 0.93 & 0.93 & 0.93 & 0.93 \\
\hline Calcium carbonate & 1 & 1 & 1 & 1 & 1 & 1.3 & 1.3 & 1.3 & 1.3 & 1.3 \\
\hline Dl-Methionine & 0.4 & 0.4 & 0.4 & 0.4 & 0.4 & 0.4 & 0.4 & 0.4 & 0.4 & 0.4 \\
\hline L-Lysine & 0.5 & 0.5 & 0.5 & 0.5 & 0.5 & 0.5 & 0.5 & 0.5 & 0.5 & 0.5 \\
\hline Vit. \& Minerals* & 0.3 & 0.3 & 0.3 & 0.3 & 0.3 & 0.3 & 0.3 & 0.3 & 0.3 & 0.3 \\
\hline Anti fungus & 0.1 & 0.1 & 0.1 & 0.1 & 0.1 & 0.1 & 0.1 & 0.1 & 0.1 & 0.1 \\
\hline Salt & 0.3 & 0.3 & 0.3 & 0.3 & 0.3 & 0.3 & 0.3 & 0.3 & 0.3 & 0.3 \\
\hline Supplemental yeast (\%) & 0 & 0.5 & 1 & 0 & 0 & 0 & 0.5 & 1 & 0 & 0 \\
\hline Supplemental bacteria (\%) & 0 & 0 & 0 & 0.5 & 1 & 0 & 0 & 0 & 0.5 & 1 \\
\hline \multicolumn{11}{|c|}{ Calculated analyses $(\%)^{* *}$} \\
\hline Crude protein (\%) & 24.00 & 24.22 & 24.32 & 24.01 & 24.02 & 20.00 & 20.22 & 20.32 & 20.01 & 20.02 \\
\hline Energy (Kcal/Kg) & 2890 & 2901 & 2910 & 2900 & 2900 & 2900 & 2901 & 2910 & 2900 & 2900 \\
\hline Calcium (\%) & 0.71 & 0.71 & 0.71 & 0.71 & 0.71 & 0.84 & 0.84 & 0.84 & 0.84 & 0.84 \\
\hline Phosphorus (\%) & 0.56 & 0.56 & 0.56 & 0.56 & 0.56 & 0.55 & 0.55 & 0.55 & 0.55 & 0.55 \\
\hline L-Lysine (\%) & 1.21 & 1.21 & 1.21 & 1.21 & 1.21 & 1.05 & 1.05 & 1.05 & 1.05 & 1.05 \\
\hline Dl-Methionine(\%) & 0.77 & 0.77 & 0.77 & 0.77 & 0.77 & 0.74 & 0.74 & 0.74 & 0.74 & 0.74 \\
\hline
\end{tabular}

Vitamins and minerals premix provides per kg of diet: $10000 \mathrm{IU}$ vitamin. A, $11.0 \mathrm{IU}$ vit. E, $1.1 \mathrm{mg}$ vitamin $\mathrm{K}$, $1100 \mathrm{ICU}$ vitamin $\mathrm{D}_{3}, 5 \mathrm{mg}$ riboflavin, $12 \mathrm{mg}$ Capantothenate, 12.1 ugvitamin. $\mathrm{B}_{12}, 2.2 \mathrm{mg}$ vitamin. $\mathrm{B} 6,2.2 \mathrm{mg}$ thiamin, $44 \mathrm{mg}$ nicotinic acid, $0.11 \mathrm{mg}$ d-biotin, $60 \mathrm{mg} \mathrm{Mn}, 50 \mathrm{mg} \mathrm{Zn}, 0.3 \mathrm{mg} \mathrm{I}, 0.1 \mathrm{mg} \mathrm{Co}, 30 \mathrm{mg} \mathrm{Fe}, 5 \mathrm{mg} \mathrm{Cu}$ and $1 \mathrm{mg}$ Se.

${ }^{* * *}$ According to Feed Composition Tables for animal \& poultry feedstuffs used in Egypt (2001).

Table (2): Composition and calculated analyses of experimental diets in grower period (28-49 days).

\begin{tabular}{lcccccccccc}
\hline Ingredient & $\begin{array}{c}\mathbf{T}_{\mathbf{1}} \\
\text { (Control) }\end{array}$ & $\mathbf{T}_{\mathbf{2}}$ & $\mathbf{T}_{\mathbf{3}}$ & $\mathbf{T}_{\mathbf{4}}$ & $\mathbf{T}_{\mathbf{5}}$ & $\mathbf{T}_{\mathbf{6}}$ & $\mathbf{T}_{\mathbf{7}}$ & $\mathbf{T}_{\mathbf{8}}$ & $\mathbf{T}_{\mathbf{9}}$ & $\mathbf{T}_{\mathbf{1 0}}$ \\
\hline Yellow corn & 63.88 & 63.88 & 63.88 & 63.88 & 63.88 & 69.98 & 69.98 & 69.98 & 69.98 & 69.98 \\
Soybean & 32.49 & 32.49 & 32.49 & 32.49 & 32.49 & 25.89 & 25.89 & 25.89 & 25.89 & 25.89 \\
Di-calcium phosphate & 0.93 & 0.93 & 0.93 & 0.93 & 0.93 & 1.18 & 1.18 & 1.18 & 1.18 & 1.18 \\
Calcium carbonate & 1.1 & 1.1 & 1.1 & 1.1 & 1.1 & 1.35 & 1.35 & 1.35 & 1.35 & 1.35 \\
Dl-Methionine & 0.4 & 0.4 & 0.4 & 0.4 & 0.4 & 0.4 & 0.4 & 0.4 & 0.4 & 0.4 \\
L-Lysine & 0.5 & 0.5 & 0.5 & 0.5 & 0.5 & 0.5 & 0.5 & 0.5 & 0.5 & 0.5 \\
Vit. \& Minerals & 0.3 & 0.3 & 0.3 & 0.3 & 0.3 & 0.3 & 0.3 & 0.3 & 0.3 & 0.3 \\
Anti fungus & 0.1 & 0.1 & 0.1 & 0.1 & 0.1 & 0.1 & 0.1 & 0.1 & 0.1 & 0.1 \\
Salt & 0.3 & 0.3 & 0.3 & 0.3 & 0.3 & 0.3 & 0.3 & 0.3 & 0.3 & 0.3 \\
Supplemental yeast (\%) & 0 & 0.5 & 1 & 0 & 0 & 0 & 1 & 0.5 & 0 & 0 \\
Supplemental bacteria (\%) & 0 & 0 & 0 & 0.5 & 1 & 0 & 0 & 0 & 0.5 & 1 \\
& & $\mathbf{C a l c u l a t e d ~ a n a l y s e s ~ ( \% ) ~}$ & & & & & & \\
Crude protein (\%) & 22.00 & 22.16 & 22.45 & 22.01 & 22.02 & 18.00 & 18.16 & 18.45 & 18.01 & 18.02 \\
Energy (Kcal/Kg) & 2903 & 2905 & 2923 & 2903 & 2903 & 2950 & 2955 & 2970 & 2950 & 2950 \\
Calcium (\%) & 0.76 & 0.76 & 0.76 & 0.76 & 0.76 & 0.90 & 0.90 & 0.90 & 0.90 & 0.90 \\
Phosphorus (\%) & 0.56 & 0.56 & 0.56 & 0.56 & 0.56 & 0.58 & 0.58 & 0.58 & 0.58 & 0.58 \\
L-Lysine (\%) & 1.10 & 1.10 & 1.10 & 1.10 & 1.10 & 0.92 & 0.92 & 0.92 & 0.92 & 0.92 \\
Dl-Methionine (\%) & 0.75 & 0.75 & 0.75 & 0.75 & 0.75 & 0.72 & 0.72 & 0.72 & 0.72 & 0.72 \\
\hline
\end{tabular}

"Vitamins and minerals premix provides per kg of diet: 10000 IU vitamin. A, $11.0 \mathrm{IU}$ vit. E, $1.1 \mathrm{mg}$ vitamin $\mathrm{K}$, $1100 \mathrm{ICU}$ vitamin $\mathrm{D}_{3}, 5 \mathrm{mg}$ riboflavin, $12 \mathrm{mg}$ Capantothenate, $12.1 \mu$ gvitamin. $\mathrm{B}_{12}, 2.2 \mathrm{mg}$ vitamin. $\mathrm{B}_{6}, 2.2 \mathrm{mg}$ thiamin, $44 \mathrm{mg}$ nicotinic acid, $0.11 \mathrm{mg}$ d-biotin, $60 \mathrm{mg} \mathrm{Mn}, 50 \mathrm{mg} \mathrm{Zn}, 0.3 \mathrm{mg} \mathrm{I}, 0.1 \mathrm{mg} \mathrm{Co}, 30 \mathrm{mg} \mathrm{Fe}, 5 \mathrm{mg} \mathrm{Cu}$ and $1 \mathrm{mg} \mathrm{Se}$.

${ }^{* * *}$ According to Feed Composition Tables for animal \& poultry feedstuffs used in Egypt (2001). 
to Jakobsen et al. (1960). At the end of the experimental period (49 day), 9 birds from each treatment, three birds from each replicate had been deprived from feed for 8 hours, then weighed and slaughtered to estimate some carcass characteristics (carcass \% and giblets \%). During slaughtering, nine samples per treatment were collected to determine the blood total protein, albumin and globulin.

\section{Economical Efficiency}

The economical efficiency for meat production was calculated according to the price of local market as well as the price of probiotic (yeast and bacteria) and prices of the ingredients at the time of the experiment. Economical efficiency= the net revenue /total cost.

\section{Statistical Analysis}

The statistical analysis was computed by using analysis of variance (factorial design using the general linear models (GLM) as described in SAS program (SAS ${ }^{\circledR}$ institute, 2004) and the significant mean differences between treatment means were distinguished by Duncan's Multiple Range Test (Duncan, 1955). All statements of significance were based on $\mathrm{P} \leq 0.05$.

The model used in the experimental was:

$\mathrm{Yij}=\mu+\mathrm{Ti}+\mathrm{e} \mathrm{ij}$

Where:

Yij $=$ the measured parameter

$\mu=$ the overall mean.

$\mathrm{Ti}=$ effect of treatments, $\mathrm{i}=(1$ to 10$)$

eij $=$ experimental error.

\section{RESULTS AND DISCUSSION}

\section{Live Body Weight and Body Weight Gain}

Effect of various dietary protein level supplemented with or without probiotic on body weight development of growing quail during the whole experimental period (7-49 day) is presented in Table 3.
Results showed that the best value $(\mathrm{P} \leq$ 0.05 ) of live body weight (LBW, g) and body weight gain (BWG, g) had been obtained by quails fed diet containing 24 and $22 \% \mathrm{CP}$ supplemented with $1 \mathrm{~g}$ yeast/ $\mathrm{kg}$ diets during starting and growing period, respectively compared to control diet and other experimental diets.

The results were also in accordance with Ghally and Abd El-Latif (2007) who reported that feeding growing quail on diet contained $24 \% \mathrm{CP}$ plus 1 or $2 \%$ yeast significantly increased live body weight and body weight gain. On the other hand, Ali et al. (2000) found that in growing Japanese quail the birds fed diet contain low level of crude protein $(22 \%)$ with 1.5 yeast culture $\mathrm{kg} / \mathrm{ton}$, significantly increased live body weight and body weight gain compared with that obtained from birds fed diets containing the high level of crude protein $(24 \%)$ with the high level of yeast culture (3 kg/ton).

\section{Feed Intake}

In the present study, quails fed diet containing low protein (20 and 18\%) during starting and growing period without probiotic consumed more $(\mathrm{P} \leq 0.05)$ feed compared to control diet and dietary supplemented with probiotic (Table 3). These results are in the same line with Selim (2015) who indicated that quail birds fed low protein diets (20\% CP) consumed more significant than those receiving $22 \%$ protein diets. The reduce feed intake in birds fed on high protein diets could be attributed to an imbalance in energy to protein. Two types of imbalance may be caused by the addition of a relatively small quantity of amino acid to a low-CP diet, which results in providing an incomplete mixture of amino acids in the feed (D' Mello, 1994).

\section{Feed Conversion Ratio}

Diets contained 24 and $22 \% \quad \mathrm{CP}$ supplemented with $1 \mathrm{~g}$ yeast $/ \mathrm{kg}$ diets resulted 
SINAI Journal of Applied Sciences (ISSN: 2314-6079) Vol. (5) Is. (1), Apr. 2016

Table (3): Effect of dietary protein level and probiotic supplementation on live body weight, body weight gain, feed intake, feed conversion ratio, and protein conversion of quail chicks during experimental period (7-49 day).

\begin{tabular}{|c|c|c|c|c|c|c|c|c|c|}
\hline \multirow[t]{2}{*}{ Trt. } & \multicolumn{2}{|c|}{$\begin{array}{c}\text { Protein levels } \\
(\%) \\
\end{array}$} & \multirow[t]{2}{*}{$\begin{array}{c}\text { Probiotic } \\
\text { level }(\mathrm{g} / \mathrm{kg})\end{array}$} & \multirow{2}{*}{$\begin{array}{c}\text { Initial } \\
\text { LBW } \\
\text { (g) }\end{array}$} & \multirow[t]{2}{*}{$\begin{array}{l}\text { LBW } \\
\text { (g) }\end{array}$} & \multirow[t]{2}{*}{$\begin{array}{c}\text { BWG } \\
\text { (g) }\end{array}$} & \multirow[t]{2}{*}{$\begin{array}{l}\text { FI } \\
\text { (g) }\end{array}$} & \multirow{2}{*}{$\begin{array}{c}\text { FCR } \\
\text { (g. feed/g. } \\
\text { gain) }\end{array}$} & \multirow{2}{*}{$\begin{array}{c}\text { PCR } \\
\text { (g. protein/g. } \\
\text { gain) }\end{array}$} \\
\hline & $\overline{\text { Starte }}$ & inisher & & & & & & & \\
\hline $\begin{array}{l}\mathrm{T}_{1} \\
\text { ontrol) }\end{array}$ & & 22 & 0 & $9.97^{\mathrm{abc}} \pm 0.33$ & $211.93^{\mathrm{cd}} \pm 2.00$ & $181.96^{\mathrm{cd}} \pm 2.34$ & $623.94^{\mathrm{cde}} \pm 2.14$ & $3.42^{\mathrm{b}} \pm 0.035$ & $0.85^{\mathrm{c}} \pm 0.014$ \\
\hline $\mathbf{T}_{2}$ & 24 & 22 & & $30.40^{\mathrm{abc}} \pm 0.15$ & $221.07^{\mathrm{c}} \pm 0.67$ & $190.67^{\mathrm{c}} \pm 4.74$ & $637.31^{\mathrm{bc}} \pm 6.64$ & $3.34^{\mathrm{b}} \pm 0.052$ & $0.90^{\mathrm{c}} \pm 0.051$ \\
\hline $\mathbf{T}_{3}$ & 2 & ? & 1 & $28.31^{\mathrm{c}} \pm 0.38$ & $261.27^{\mathrm{a}} \pm 3.42$ & $232.95^{\mathrm{a}} \pm 3.67$ & $39.37^{\mathrm{bc}} \pm 3.21$ & $2.74^{\mathrm{c}} \pm 0.029$ & $1.55^{\mathrm{a}} \pm 0.046$ \\
\hline $\mathbf{T}_{4}$ & 24 & 22 & $05 \mathrm{~h}$ & $29.00^{b c} \pm 1.17$ & $7.43^{\mathrm{cd}_{1}} \pm 4.41$ & $178.43^{\mathrm{dc}} \pm 3.88$ & $03.07^{\mathrm{e}} \pm 7.47$ & $3.38^{\mathrm{b}} \pm 0.033$ & $0.86^{\mathrm{c}} \pm 0.035$ \\
\hline $\mathbf{T}_{5}$ & 2 & 22 & $10 \mathrm{~h}$ & $28.66^{\mathrm{bc}} \pm 1.15$ & $218.43^{\mathrm{c}} \pm 3.78$ & $189.77^{\mathrm{c}} \pm 3.58$ & $640.68 b c \pm 6.26$ & $3.38^{\mathrm{b}} \pm 0.041$ & $0.93^{c} \pm 0.067$ \\
\hline $\mathbf{T}_{6}$ & 20 & 18 & 0 & $29.97^{\mathrm{abc}} \pm 0.33$ & $202.77^{\mathrm{d}} \pm 1.05$ & $174.09^{\mathrm{d}} \pm 4.17$ & $681.20^{\mathrm{a}} \pm 4.29$ & $3.91^{\mathrm{a}} \pm 0.083$ & $0.82^{\mathrm{c}} \pm 0.053$ \\
\hline $\mathbf{T}_{7}$ & 20 & 18 & st & $30.75^{\mathrm{ab}} \pm 0.94$ & $221.40^{\mathrm{c}} \pm 3.01$ & $190.64^{\mathrm{c}} \pm 2.85$ & $651.64^{b} \pm 5.73$ & $3.42^{\mathrm{b}} \pm 0.045$ & $0.94^{\mathrm{c}} \pm 0.057$ \\
\hline $\mathbf{T}_{8}$ & 20 & 18 & 1.0 yeast & $29.66^{\mathrm{abc}} \pm 0.57$ & $236.03^{\mathrm{b}} \pm 3.20$ & $206.37^{\mathrm{b}} \pm 1.71$ & $611.09^{\mathrm{de}_{\mathrm{e}}} \pm 2.26$ & $2.96^{\mathrm{c}} \pm 0.014$ & $1.28^{\mathrm{b}} \pm 0.048$ \\
\hline $\mathbf{T}_{9}$ & 20 & 18 & 0.5 bact & $31.59^{\mathrm{a}} \pm 0.24$ & $210.17^{\mathrm{cd}} \pm 6.64$ & $178.59^{\mathrm{cd}} \pm 11.37$ & $626.22^{\text {cd }} \pm 9.53$ & $3.53^{\mathrm{b}} \pm 0.014$ & $0.89^{c} \pm 0.105$ \\
\hline$T_{10}$ & 20 & 18 & 1.0 bacteria & $29.97^{\mathrm{abc}} \pm 0.33$ & $219.70^{c} \pm 3.37$ & $181.95^{\mathrm{cd}} \pm 2.34$ & $623.94^{\mathrm{cde}^{2}} \pm 2.14$ & $3.42^{\mathrm{b}} \pm 0.035$ & $0.85^{\mathrm{c}} \pm 0.014$ \\
\hline
\end{tabular}

$\mathrm{a}, \mathrm{b}, \mathrm{c}, \ldots$, etc means in the same column with the different litters are significantly different $(\mathrm{P} \leq 0.05)$.

Live Body Weight (LBW, g)

Feed Intake (FI, g/bird)

Body Weight Gain $(B W G, g)=$ final weight $(\mathrm{g})$ - initial weight $(\mathrm{g})$

Feed Conversion Ratio $(\mathrm{FCR})=$ feed intake $(\mathrm{g}) /$ weight gain $(\mathrm{g})$

Protien Conversion Ratio $(\mathrm{PCR})=$ protien intake $(\mathrm{g}) /$ weight gain $(\mathrm{g})$

in better $(\mathrm{P} \leq 0.05)$ FCR than control diet and other experimental diets (Table 2). This finding is in agreement with Abd ElMaksoud et al. (2010) who found that hens fed diet containing $16 \% \mathrm{CP}$ with dried yeast $(250 \mathrm{mg} / \mathrm{kg}$ diet $)$ showed the best value of feed conversion ratio compared with other groups. On the other sides, Ali et al. (2000) indicated that quail birds fed a $22 \% \mathrm{CP}$ diet with high level of yeast culture (3 kg/ton) significantly $(\mathrm{P} \leq 0.05)$ improved feed conversion ratio compared with other groups.

\section{Protein Conversion Ratio}

Birds fed diets containing 24 and $22 \%$ in starting and growing period, respectively supplemented with $1 \mathrm{~g}$ yeast/ $\mathrm{kg}$ diets achieved the best $(\mathrm{P} \leq 0.05)$ protein conversions ratios (PCR, g. protein intake/ g. gain) to control diet and dietary supplemented with probiotic (Table 3 ). In contrary of this study Ali et al. (2000) indicated that birds fed a $22 \% \mathrm{CP}$ diet with high level of yeast culture (3 $\mathrm{kg} / \mathrm{ton})$ significantly decreased $(\mathrm{P} \leq 0.05)$ protein conversion ratio compared with other groups.

The improvement in the body weight, weight gain, feed intake, feed conversion ratio and protein conversion ratio in this study may be due to the increased efficiency of digestion and nutrient absorption processes due to presence of the probiotic. Edens (2003) reported that the inclusion of desirable microorganisms (probiotics) in the diet allows the rapid development of beneficial bacteria in the digestive tract of the host, improving its performance. As a consequence, there is an improvement in the intestinal environment, increasing the efficiency of digestion and nutrient absorption processes. Edens et al. (1997) showed that in vivo and exvivo administration of Lactobacillus reuteri resulted in an increased villus height, indicating that probiotics are potentially able to enhance nutrient absorption and thereby improve growth performance and feed efficiency. 


\section{Digestion Coefficients and Nitrogen Balance}

Digestion coefficient of nutrients were significantly $(\mathrm{P} \leq 0.05)$ affected by crude protein level supplemented with probiotic (Table 4). Birds fed diets containing 24 and $22 \%$ in starting and growing periods, respectively supplemented with $1 \mathrm{~g}$ yeast/ $\mathrm{kg}$ diet gave the best digestion coefficient values of all nutrients compared to control and other diets. Nitrogen balance (Table 4) was higher for birds fed diets containing 20 and $18 \% \mathrm{CP}$ in starting and growing periods, respectively supplemented with $1 \mathrm{~g}$ yeast/ kg diets compared to control diet and other treatment groups.

\section{Carcass Characteristics}

Birds fed diets containing low $\mathrm{CP}$ level (20 and 18\%) supplemented with $0.5 \mathrm{~g}$ bacteria/kg diet during starting and finishing periods increased significantly $(\mathrm{P} \leq 0.05)$ the carcass weight and percentage compared to control diet and other experimental diets (Table 5).

The highest value of giblets weight and percentage had been recorded for birds fed low protein (20 and $18 \% \mathrm{CP})$ without probiotic.

This results are in agreement with Selim (2015) who found that quail birds fed diets contained low protein $(22 \% \mathrm{CP})$ increased average carcass weight, carcass weight (\%), giblet weight and giblet weight (\%) compared with birds fed low protein (20\%). In contrary, Mohamed et al. (2015) found that there were no significant differences in hot carcass, eviscerated and dressing percentage and relative percentage of internal organs (gizzard, heart, liver and spleen) between broiler duck fed basal diets with or without probiotic.

\section{Total Protein, Albumin and Globulin}

Results in Table (6) show that, adding $1 \%$ yeast culture to quail diet containing low crude protein (20 and 18\%) enhanced $(\mathrm{P}<0.05)$ plasma total protein and globulin compared with the control diet and other treatments. However, no significant effect were observed in serum albumin between all treatments. In contrary, of this study, Mohamed et al. (2015) found no significant effect in serum total protein, albumin, globulin, of broiler ducks fed diets contained $16 \%$ protein with $0.1 \%$ probiotics (Saccharomyces cerevisiae).

\section{Economic Efficiency}

The net revenue and economical efficiency values varied from 3.51-2.80 and 0.45-0.81 L.E., respectively (Table 7).

The lowest values of net revenue and economical efficiency were recorded for quails fed diet containing 24 and $22 \% \mathrm{CP}$ supplemented with $0.5 \mathrm{~g}$ bacteria $/ \mathrm{kg}$ diets. While the highest values were calculated for other fed diets containing 24 and $22 \% \mathrm{CP}$ supplemented with $1 \mathrm{~g}$ yeast $/ \mathrm{kg}$ diet. These results are in agreement with Abd ElMaksoud (2010) who found the best economic efficiency (EE) and relative economic efficiency (REE) achieved in chick fed diet containing $16 \% \mathrm{CP}$ with dried yeast $250 \mathrm{mg} / \mathrm{kg}$. On the other hand Ali et al. (2000) showed that quails fed diets contain low protein supplemented with yeast culture $(1.53 \mathrm{~kg} / \mathrm{ton})$ numerically had the best EE and REE.

\section{Conclusion}

From the obtained results it can be concluded that 24 and $22 \%$ crude protein content with $1 \mathrm{~g}$ yeast $/ \mathrm{kg}$ diet in starting and growing periods, respectively in growing quail ration improve growth performance without any side effects and achieved the best economic efficiency. 
SINAI Journal of Applied Sciences (ISSN: 2314-6079) Vol. (5) Is. (1), Apr. 2016

Table (4): Effect of dietary protein level and probiotic supplementation on digestion coefficient and nitrogen balance (\%) of growing quail.

\begin{tabular}{|c|c|c|c|c|c|c|c|c|c|c|}
\hline \multirow[t]{2}{*}{ Trt. } & \multicolumn{2}{|c|}{$\begin{array}{c}\text { Protein levels } \\
\text { (\%) }\end{array}$} & \multirow{2}{*}{$\begin{array}{c}\text { Probiotic } \\
\text { level }(g / k g)\end{array}$} & \multirow[t]{2}{*}{$\overline{D M}$} & \multirow[t]{2}{*}{$\overline{C P}$} & \multirow[t]{2}{*}{$\overline{\mathbf{E E}}$} & \multirow[t]{2}{*}{$\overline{C F}$} & \multirow[t]{2}{*}{$\overline{\mathrm{OM}}$} & \multirow[t]{2}{*}{ NFE } & \multirow[t]{2}{*}{$\overline{\text { NB }}$} \\
\hline & $\overline{\text { Starter }}$ & inisher & & & & & & & & \\
\hline $\begin{array}{c}\mathrm{T}_{1} \\
\text { (control) }\end{array}$ & 24 & 22 & 0.00 & $71.23 \mathrm{e} \pm 0.20$ & $94.13 c \pm 0.12$ & $81.37 \mathrm{~d} \pm 0.33$ & $25.10 \mathrm{~d} \pm 0.10$ & $74.33 \mathrm{ef} \pm 0.18$ & $72.20 \mathrm{c} \pm 0.10$ & $\overline{54.27 \mathrm{~d} \pm 0.03}$ \\
\hline $\mathbf{T}_{2}$ & 24 & 22 & 0.5 yeast & $55.30 \mathrm{c} \pm 0.06$ & $73.20 \mathrm{c} \pm 0.20$ & $95.10 \mathrm{~b} \pm 0.06$ & $84.00 \mathrm{~b} \pm 0.06$ & $22.50 \mathrm{e} \pm 0.17$ & $76.70 \mathrm{c} \pm 0.25$ & $73.63 b c \pm 0.15$ \\
\hline $\mathbf{T}_{3}$ & 24 & 22 & 1.0 yeast & $59.47 \mathrm{a} \pm 0.28$ & $76.40 \mathrm{a} \pm 0.06$ & $96.60 \mathrm{a} \pm 0.11$ & $86.47 a \pm 0.27$ & $28.53 a \pm 0.18$ & $78.87 \mathrm{a} \pm 0.34$ & $74.56 \mathrm{~b} \pm 1.42$ \\
\hline $\mathbf{T}_{4}$ & 24 & 22 & 0.5 bacteria & $55.17 \mathrm{~cd} \pm 0.09$ & $72.43 \mathrm{~d} \pm 0.07$ & $95.13 b \pm 0.09$ & $82.57 \mathrm{c} \pm 0.26$ & $22.47 \mathrm{e} \pm 0.09$ & $75.57 \mathrm{~d} \pm 0.20$ & $73.70 b c \pm 0.11$ \\
\hline $\mathbf{T}_{5}$ & 24 & 22 & 1.0 bacteria & $56.97 \mathrm{~b} \pm 0.49$ & $72.10 \mathrm{~d} \pm 0.10$ & $95.20 \mathrm{~b} \pm 0.06$ & $84.2 \mathrm{~b} \pm 0.18$ & $27.30 \mathrm{~b} \pm 0.35$ & $75.10 \mathrm{ed} \pm 0.25$ & $73.83 \mathrm{~b} \pm 0.12$ \\
\hline $\mathbf{T}_{6}$ & 20 & 18 & 0.00 & $50.27 \mathrm{e} \pm 0.23$ & $71.43 \mathrm{e} \pm 0.29$ & $93.53 \mathrm{e} \pm 0.13$ & $83.40 \mathrm{c} \pm 0.30$ & $23.03 \mathrm{e} \pm 0.08$ & $74.17 \mathrm{e} \pm 0.14$ & $73.67 b c \pm 0.18$ \\
\hline $\mathbf{T}_{7}$ & 20 & 18 & 0.5 yeast & $45.33 \mathrm{f} \pm 0.29$ & $75.23 b \pm 0.24$ & $93.20 \mathrm{ef} \pm 0.15$ & $83.73 \mathrm{c} \pm 0.22$ & $23.17 \mathrm{e} \pm 0.60$ & $73.67 \mathrm{f} \pm 0.88$ & $77.33 a \pm 0.33$ \\
\hline $\mathbf{T}_{8}$ & 20 & 18 & 1.0 yeast & $42.40 \mathrm{~g} \pm 0.26$ & $76.00 \mathrm{a} \pm 0.06$ & $93.07 \mathrm{f} \pm 0.03$ & $84.87 b \pm 0.09$ & $26.13 \mathrm{c} \pm 0.03$ & $77.67 \mathrm{~b} \pm 0.12$ & $77.63 \mathrm{a} \pm 0.09$ \\
\hline $\mathbf{T}_{9}$ & 20 & 18 & 0.5 bacteria & $46.20 \mathrm{f} \pm 0.60$ & $73.17 \mathrm{c} \pm 0.03$ & $93.63 \mathrm{de} \pm 0.32$ & $83.93 c \pm 0.07$ & $22.30 \mathrm{e} \pm 0.30$ & $75.87 \mathrm{~d} \pm 0.44$ & $77.60 \mathrm{a} \pm 0.06$ \\
\hline$T_{10}$ & 20 & 18 & 1.0 bacteria & $46.23 \mathrm{f} \pm 0.20$ & $73.63 \mathrm{c} \pm 0.09$ & $94.03 \mathrm{~d} \pm 0.12$ & $84.53 b \pm 0.03$ & $25.00 \mathrm{~d} \pm 0.35$ & $75.63 \mathrm{~cd} \pm 0.20$ & $76.60 \mathrm{a} \pm 0.21$ \\
\hline
\end{tabular}

$\mathrm{a}, \mathrm{b}, \mathrm{c}, \ldots$, et $c$ means in the same column with the different litters are significantly different $(\mathrm{P} \leq 0.05)$.

Dry Matter (DM), Organic Matter (OM), Crude Protein (CP), Crude Fiber (CF), Ether Extract (EE), and Nitrogen Free Extract (NFE)

Table (5): Effect of dietary protein level and probiotic supplementation on carcass characteristics of growing quail.

\begin{tabular}{|c|c|c|c|c|c|c|c|}
\hline \multirow[t]{2}{*}{ Trt. } & \multicolumn{2}{|c|}{ Protein levels (\%) } & \multirow{2}{*}{$\begin{array}{l}\text { Probiotic } \\
\text { level (g/kg) }\end{array}$} & \multirow{2}{*}{$\begin{array}{c}\text { Caracas } \\
\text { weight (g) }\end{array}$} & \multirow{2}{*}{$\begin{array}{l}\text { Caracas weight } \\
(\%) \text { of } L B W\end{array}$} & \multirow{2}{*}{$\begin{array}{l}\text { Giblet weight } \\
\text { (g) }\end{array}$} & \multirow{2}{*}{$\begin{array}{l}\text { Giblet weight } \\
\text { (\%) of LBW }\end{array}$} \\
\hline & Starter & $\overline{\text { Finisher }}$ & & & & & \\
\hline $\begin{array}{c}\mathrm{T}_{1} \\
\text { (control) }\end{array}$ & 24 & 22 & 0.00 & $140.77^{\mathrm{bc}} \pm 6.80$ & $69.67^{\mathrm{bc}} \pm 2.33$ & $9.50^{\mathrm{b}} \pm 0.79$ & $4.66^{\mathrm{abc}} \pm 0.26$ \\
\hline $\mathbf{T}_{2}$ & 24 & 22 & 0.5 yeast & $153.88^{\mathrm{ab}} \pm 0.06$ & $74.41^{\mathrm{ab}} \pm 3.26$ & $8.84^{\mathrm{b}} \pm 0.37$ & $4.34^{\mathrm{b}} \pm 0.25$ \\
\hline $\mathbf{T}_{3}$ & 24 & 22 & 1.0 yeast & $157.22^{\mathrm{ab}} \pm 4.00$ & $68.72^{\mathrm{bc}} \pm 1.84$ & $9.80^{\mathrm{b}} \pm 0.49$ & $4.25^{\mathrm{c}} \pm 0.12$ \\
\hline $\mathbf{T}_{4}$ & 24 & 22 & 0.5 bacteria & $128.33^{\mathrm{c}} \pm 7.94$ & $69.30^{\mathrm{bc}} \pm 0.85$ & $9.78^{\mathrm{b}} \pm 0.89$ & $5.59^{\mathrm{ab}} \pm 0.91$ \\
\hline $\mathbf{T}_{5}$ & 24 & 22 & 1.0 bacteria & $128.88^{\mathrm{c}} \pm 7.44$ & $65.56^{\mathrm{c}} \pm 4.72$ & $9.03^{\mathrm{b}} \pm 0.58$ & $4.63^{\mathrm{abc}} \pm 0.39$ \\
\hline$T_{6}$ & 20 & 18 & 0.00 & $161.11^{\mathrm{ab}} \pm 6.33$ & $72.13^{\mathrm{abc}} \pm 1.73$ & $12.74^{\mathrm{a}} \pm 0.93$ & $5.67^{\mathrm{a}} \pm 0.32$ \\
\hline $\mathbf{T}_{7}$ & 20 & 18 & 0.5 yeast & $150.00^{\mathrm{ab}} \pm 4.08$ & $73.63^{\mathrm{ab}} \pm 1.66$ & $9.77^{\mathrm{b}} \pm 0.65$ & $4.77^{\mathrm{abc}} \pm 0.26$ \\
\hline $\mathbf{T}_{8}$ & 20 & 18 & 1.0 yeast & $157.22^{\mathrm{ab}} \pm 7.17$ & $72.29^{\mathrm{abc}} \pm 2.76$ & $10.54 \pm 0.81$ & $4.82^{\mathrm{abc}} \pm 0.35$ \\
\hline $\mathbf{T}_{9}$ & 20 & 18 & 0.5 bacteria & $170.55^{\mathrm{a}} \pm 5.16$ & $77.83^{\mathrm{a}} \pm 1.47$ & $10.4^{\mathrm{b}} \pm 0.51$ & $4.78^{\mathrm{abc}} \pm 0.22$ \\
\hline$T_{10}$ & 20 & 18 & 1.0 bacteria & $161.66^{\mathrm{ab}} \pm 4.33$ & $73.26^{\mathrm{abc}} \pm 0.98$ & $12.51^{\mathrm{a}} \pm 0.48$ & $5.72^{\mathrm{a}} \pm 0.34$ \\
\hline
\end{tabular}

$\mathrm{a}, \mathrm{b}, \mathrm{c}, \ldots$, etc. means in the same column with the different litters are significantly different $(\mathrm{P} \leq 0.05)$. 
Table (6): Effect of dietary protein level and probiotic supplementation on blood parameters of growing quail.

\begin{tabular}{cccccccc}
\hline Trt & \multicolumn{2}{c}{$\begin{array}{c}\text { Protein } \\
\text { levels (\%) }\end{array}$} & $\begin{array}{c}\text { Probiotic } \\
\text { level (g/kg) }\end{array}$ & $\begin{array}{c}\text { Total } \\
\text { protein }\end{array}$ & Albumin & Globulin & $\begin{array}{c}\text { A/G } \\
\text { ratio }\end{array}$ \\
\cline { 2 - 6 } & Starter & Finisher & & & & & \\
\hline $\begin{array}{c}\mathbf{T}_{\mathbf{1}} \\
\text { (control) }\end{array}$ & $\mathbf{2 4}$ & $\mathbf{2 2}$ & $\mathbf{0 . 0 0}$ & $2.69^{\mathrm{c}} \pm 0.23$ & $1.26 \pm 0.15$ & $1.54^{\mathrm{d}} \pm 0.04$ & $0.82 \pm 0.11$ \\
$\mathbf{T}_{\mathbf{2}}$ & $\mathbf{2 4}$ & $\mathbf{2 2}$ & $\mathbf{0 . 5}$ yeast & $2.72^{\mathrm{c}} \pm 0.03$ & $1.25 \pm 0.11$ & $1.54^{\mathrm{d}} \pm 0.04$ & $0.81 \pm 0.07$ \\
$\mathbf{T}_{\mathbf{3}}$ & $\mathbf{2 4}$ & $\mathbf{2 2}$ & $\mathbf{1 . 0}$ yeast & $2.88^{\mathrm{abc}} \pm 0.24$ & $1.25 \pm 0.20$ & $1.70^{\mathrm{bcd}} \pm 0.05$ & $0.74 \pm 0.13$ \\
$\mathbf{T}_{\mathbf{4}}$ & $\mathbf{2 4}$ & $\mathbf{2 2}$ & $\mathbf{0 . 5}$ bacteria & $2.77^{\mathrm{bc}} \pm 0.03$ & $1.07 \pm 0.02$ & $1.70^{\mathrm{bcd}} \pm 0.05$ & $0.63 \pm 0.02$ \\
$\mathbf{T}_{\mathbf{5}}$ & $\mathbf{2 4}$ & $\mathbf{2 2}$ & $\mathbf{1 . 0}$ bacteria & $2.84^{\mathrm{abc}} \pm 0.15$ & $1.13 \pm 0.13$ & $1.63^{\mathrm{cd}} \pm 0.01$ & $0.69 \pm 0.08$ \\
$\mathbf{T}_{\mathbf{6}}$ & $\mathbf{2 0}$ & $\mathbf{1 8}$ & $\mathbf{0 . 0 0}$ & $3.00^{\mathrm{abc}} \pm 0.18$ & $1.21 \pm 0.06$ & $1.77^{\mathrm{abc}} \pm 0.11$ & $0.68 \pm 0.01$ \\
$\mathbf{T}_{7}$ & $\mathbf{2 0}$ & $\mathbf{1 8}$ & $\mathbf{0 . 5}$ yeast & $2.85^{\mathrm{abc}} \pm 0.24$ & $1.13 \pm 0.09$ & $1.74^{\mathrm{bcd}} \pm 0.21$ & $0.66 \pm 0.06$ \\
$\mathbf{T}_{\mathbf{8}}$ & $\mathbf{2 0}$ & $\mathbf{1 8}$ & $\mathbf{1 . 0}$ yeast & $3.38^{\mathrm{a}} \pm 0.18$ & $1.26 \pm 0.04$ & $2.09^{\mathrm{a}} \pm 0.10$ & $0.65 \pm 0.01$ \\
$\mathbf{T}_{\mathbf{9}}$ & $\mathbf{2 0}$ & $\mathbf{1 8}$ & $\mathbf{0 . 5}$ bacteria & $3.30^{\mathrm{ab}} \pm 0.14$ & $1.33 \pm 0.14$ & $2.01^{\mathrm{ab}} \pm 0.04$ & $0.66 \pm 0.06$ \\
$\mathbf{T}_{\mathbf{1 0}}$ & $\mathbf{2 0}$ & $\mathbf{1 8}$ & $\mathbf{1 . 0}$ bacteria & $3.34^{\mathrm{ab}} \pm 0.01$ & $1.32 \pm 0.03$ & $1.88^{\mathrm{abc}^{\mathrm{abc}} \pm 0.10}$ & $0.63 \pm 0.03$ \\
\hline
\end{tabular}

$\mathrm{a}, \mathrm{b}, \mathrm{c}, \ldots$, etc. means in the same column with the different litters are significantly different $(\mathrm{P} \leq 0.05)$.

Table (7): Effect of dietary protein level and probiotic supplementation on economic efficiency of growing quail.

\begin{tabular}{ccccccccccc}
\hline Trt & $\begin{array}{c}\text { Protein } \\
\text { level (\%) }\end{array}$ & $\begin{array}{c}\text { Probiotics } \\
(\mathbf{g} / \mathbf{k g})\end{array}$ & $\begin{array}{c}\text { Fixed } \\
\text { cost } \\
(\mathbf{L E})\end{array}$ & $\begin{array}{c}\text { Feed } \\
\text { cost } \\
\text { of } \mathbf{~ k g}\end{array}$ & $\begin{array}{c}\text { Total } \\
\text { cost } \\
(\mathbf{L E})\end{array}$ & $\begin{array}{c}\text { LBW } \\
(\mathbf{K g})\end{array}$ & $\begin{array}{c}\text { Total } \\
\text { revenue } \\
(\mathbf{l E})\end{array}$ & $\begin{array}{c}\text { Net } \\
\text { revenue } \\
(\mathbf{L . E})\end{array}$ & EE & REE \\
\hline $\begin{array}{c}\mathbf{T}_{\mathbf{1}} \\
\text { (control) }\end{array}$ & $24-22$ & 0.00 & 2 & 2.22 & 4.22 & 212 & 6.36 & 2.14 & 0.50 & 100 \\
$\mathbf{T}_{\mathbf{2}}$ & $24-22$ & 0.5 yeast & 2 & 2.25 & 4.25 & 221 & 6.63 & 2.38 & 0.56 & 110 \\
$\mathbf{T}_{\mathbf{3}}$ & $24-22$ & 1.0 yeast & 2 & 2.29 & 4.29 & 261 & 7.8 & 3.51 & 0.81 & 146 \\
$\mathbf{T}_{\mathbf{4}}$ & $24-22$ & 0.5 bacteria & 2 & 2.33 & 4.33 & 207 & 6.21 & 1.88 & 0.43 & 53 \\
$\mathbf{T}_{\mathbf{5}}$ & $24-22$ & 1.0 bacteria & 2 & 2.38 & 4.38 & 218 & 6.54 & 2.16 & 0.49 & 113 \\
$\mathbf{T}_{\mathbf{6}}$ & $20-18$ & 0.00 & 2 & 2.20 & 4.2 & 203 & 6.09 & 1.89 & 0.45 & 91 \\
$\mathbf{T}_{7}$ & $20-18$ & 0.5 yeast & 2 & 2.25 & 4.25 & 221 & 6.63 & 2.38 & 0.56 & 124 \\
$\mathbf{T}_{\mathbf{8}}$ & $20-18$ & 1.0 yeast & 2 & 2.28 & 4.28 & 236 & 7.08 & 2.80 & 0.65 & 117 \\
$\mathbf{T}_{\mathbf{9}}$ & $20-18$ & 0.5 bacteria & 2 & 2.32 & 4.32 & 210 & 6.3 & 1.98 & 0.45 & 70 \\
$\mathbf{T}_{\mathbf{1 0}}$ & $20-18$ & 1.0 bacteria & 2 & 2.38 & 4.38 & 220 & 6.6 & 2.22 & 0.50 & 110 \\
\hline
\end{tabular}

Fixed cost: Bird price and rearing cost.

Price of $\mathrm{kg} /$ yeast $=10 \mathrm{LE}$.

Price of $\mathrm{kg} / \mathrm{bacteria}=80 \mathrm{LE}$.

Total revenue: Assuming that the selling price of one $\mathrm{kg}$ live body weight is $30 \mathrm{LE}$.

Net revenue: Total revenue - total cost.

Economic efficiency (EE): Net revenue per unit total cost.

Relative economic efficiency (REE): Assuming that the relative economic efficiency of the control. 


\section{REFERENCES}

AOAC (2000). Official Methods of Analysis. Chemists. $17^{\text {th }}$ Ed. Association of Official Analytical Chemists. Washington, D.C. USA.

Abdel Maksoud, A.; Yan, F.; Cerrate, S.; Coto, C.; Wang, Z. and Waldroup, P.W. (2010). Effect of dietary crude protein, lysine level and amino acid balance on performance of broilers 0 to 18 days of age. Int. J. Poult. Sc., 9: 2127.

Ali, A.M.; El-Nagmy, K.Y. and AbdAlsamee, M.O. (2000). The effect of dietary protein and yeast culture levels on performance of growing Japanese quails. Egypt. Poult. Sc., 20 (IV Dec.): 777-87.

Banerjee, G.C. (1992). Poultry $\left(3^{\text {rd }} \mathrm{Ed}\right)$. Oxford and IBH publishing Co. Pvt. Ltd, New Delhi, pp.168-172.

Bariha, S.K.; Panda, N.; Mishra, P.K.; Pati, P.K. and Behera, P.C. (2010). Performance of Japanese quails under different energy and protein levels in hot and humid conditions. Indian J. Poult. Sc., 45 (3): 302-307.

Central Avian Research Institute. Izantnagar, India, Poul Abstract, 10 (1): 984.

D'Mello, J.P.F. (1994). Amino acid imbalance antagonism and toxicities in: Amino acids in Farm Animal Nutrition (Ed. D’Mello, J.P.F.), CAB International, 62-97.

Duncan, D.B. (1955). Multiple Range and Multiple F-testes. Biometrics, 11: 1-42.

Edens, F.W. (2003). An alternative for antibiotic use in poultry probiotics. Brazilian Sc, 75-97.

Edens, F.W.; Parkhurst, C.R.; Casas, I.A. and Dobrogosz, W.J. (1997). Principles of ex vivo competitive exclusion and in vivo administration of Lactobacillus reuteri. Poult. Sci.,76 : 179-196.
Fuller, R. (1989). Probiotics in man and animals. App Bacteriology 66: 365-378.

Ghally, K.A. and Abd El-Latif, S.A. (2007). Effect of dietary yeast on some productive and physiological aspects of growing Japanese quails. African Crop Sc., Conf . Proc. (8): 2147-2151.

Gibson, G.R. and Roberfroid, M. (2008). Handbook of Prebiotics: CRC Press, Taylor and Francis Group. 7-451.

Jakobsen, P.E.; Kirston, S.G. and Nelson, H. (1960). Digestibility trials with poultry. 322 bertning frafors gslaboratoriet, udgivet of stants. Husdyrbugsudvaly-Kabenhaven.

Mohamed R.I.; Gamal, M.M.; Abdelstar M. and Abd-ellah, M. (2015). Effect of feeding probiotic on performance of broiler ducks fed different protein Levels. J. of Adv. Vet. Res. 5(3): 99108.

Mountzouris, K.C.; Tsirtsikos, P. Kalamara, E.; Nitsch, S.; Schatzmayr, G. and Fegeros, K. (2007). Evaluation of the efficacy of a probioticcontaining Lactobacillus, Bifidobacterium, Enterococcus, and Pediococcusstrains in promoting broiler performance and modulatingcecal microflora composition and metabolic activities. Poult Sc. 86: 309-317.

Nahashon, S.N.; Nakne, H.S. and Mirosh, L.W. (1994). Production variables and nutrient retention in single comb white leghorn laying pullets fed diets supplemented with direct-fedmicrobials. Poult. Sci., 73: 1699-1711.

NRC, National Research Council (1994). Nutrient Requirements of Poultry. $9^{\text {th }}$ Ed., National Academy of Sciences. Washington. DC., USA.

Patterson, J.A. and Burkholder, K.M. (2014). Application of prebiotic and prebiotics in poultry production. Poul Sci., 82: 627-631. 
Rolfe, R.D. (2000). The role of probiotic cultures in the control of gastrointestinal health. J. Nut., 130: 3965-4025.

SAS (2004). SAS/STAT User's Guide. SAS Institute Inc., Cary, N.C.

Selim, M.M. (2015). Effect of different levels of protein, methionine and folic acid on growth performance of quail. M.Sc., Thesis, Fac. Agric., Cairo Univ., Egypt.
Shrivastav, A.K.; Panda, B. and Reddy, V.R. (1999). Feeding of quails in tropics: Effect of amount of protein and energy in diet of Japanese quail. Avi. Coltura, 52 (8): 23-26.

Singh, R.A. (1990). Poultry production, $3^{\text {rd }}$ Ed. Kalyany publishers, New Delhi, Ludhiana.

World Health Organization (2001). Classification of hepatic hydatid cysts. 


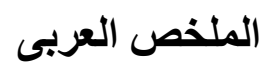

\section{تأثير المستويات المختلفة من البروتين والمعزز الحيوي على الأداء الإنتاجى للسمان}

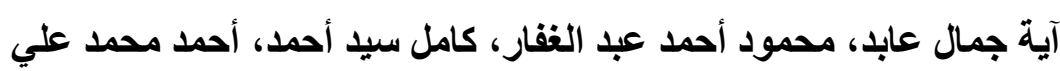

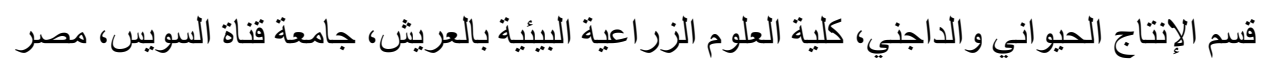

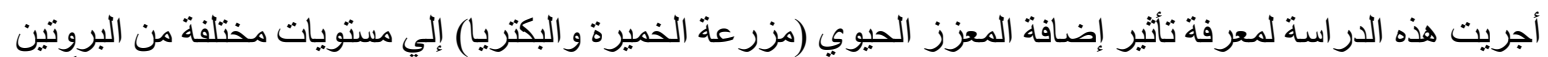

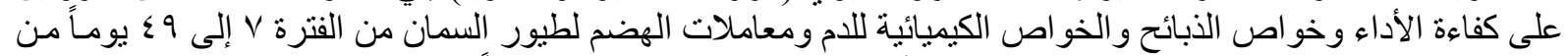

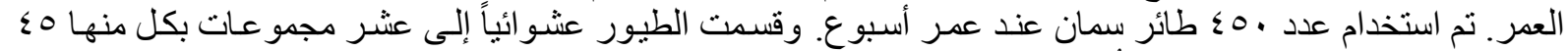

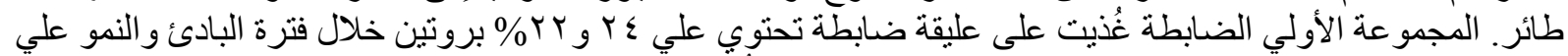

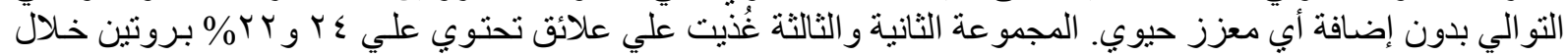

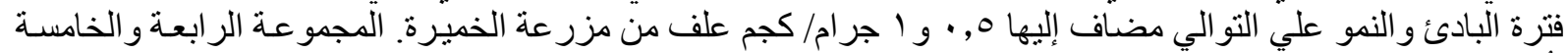

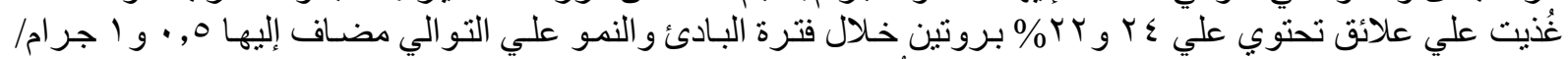

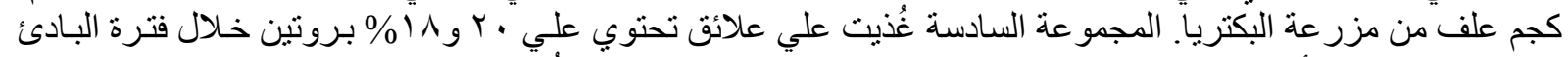

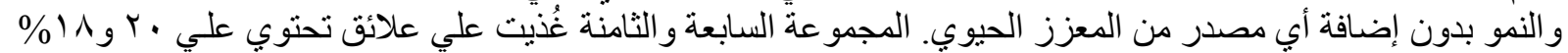

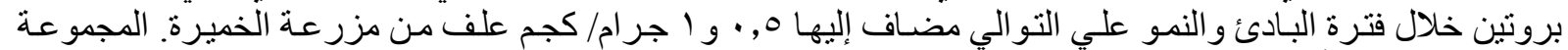

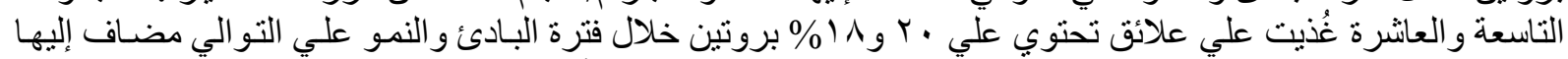

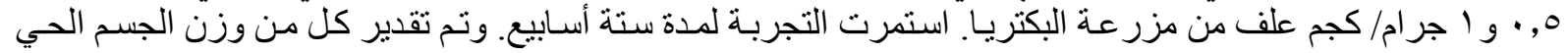

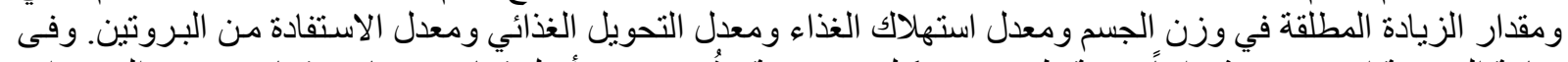

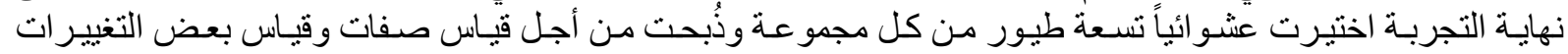

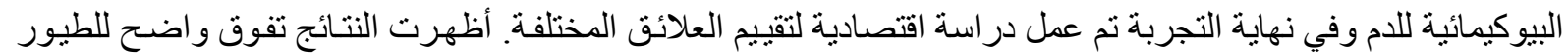

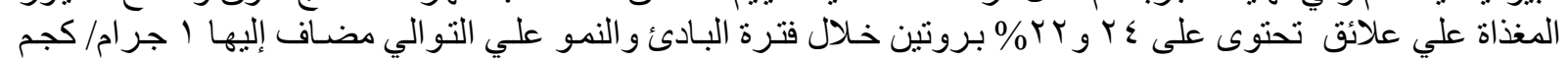

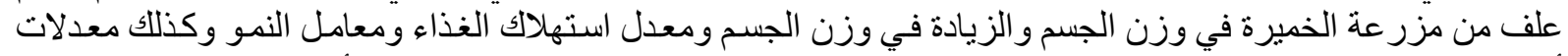

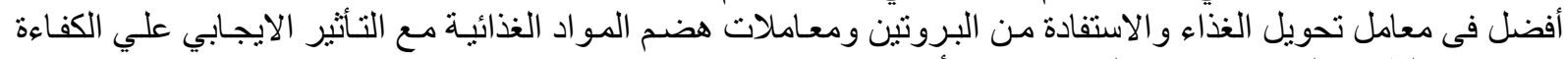

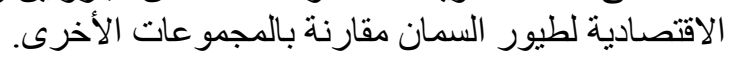

الكلمات الاسترشادية: خميرة Saccharomyces cerevisiae، حمض اللاكتياك، السمان، أداء النمو، الذيحة، الخصائص، معاملات الدم، معامل الهضم.

أستاذ الإنتاج الحيوانى، كلية الزر اعة، جامعة القاهرة، مصر . الإن.

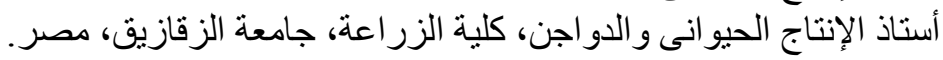

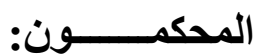

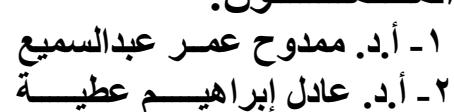


